\title{
Constructing the Hybrid Identity of the 'Stranger': The Case of Greek Immigrants in Canada
}

\author{
Rania Karachaliou \\ University of Patras, Greece \\ ramelene@gmail.com
}

\section{Villy Tsakona}

National and Kapodistrian University of Athens, Greece

villytsa@otenet.gr

\section{Argiris Archakis}

University of Patras, Greece

archakis@upatras.gr

\section{Angela Ralli}

University of Patras, Greece

ralli@upatras.gr

\begin{abstract}
The aim of our study is to examine the multiple ways Greek immigrants position themselves in terms of cultural identity. Recent approaches to immigrants' cultural identities tend to employ the concept of transnationalism to account for their hybridity and fluidity. Here, we intend to show that Georg Simmel's ([1908] 1971) notion of the 'stranger' is also relevant to the analysis and interpretation of such transnational identities. In this context, and drawing on positioning theory (Davies and Harré 1990), we argue that our informants mainly construct hybrid 'stranger' identities as both Greeks and Canadians or as feeling Greek but not when in Greece. Our data consists of 15 semi-structured interviews exploring the immigrant experiences of Greeks who migrated to Canada from the mid-1940s until the late 1970s. The analysis focuses on (a) the discursive means the informants employ to construct the hybrid identity of the 'stranger', and (b) the specific purposes they fulfill. It appears that hybrid self-positionings are achieved via the use of (a) the disclaimer 'I am/feel Greek but...', (b) metaphors, (c) small stories, and $(d)$ repair mechanisms. We also argue that, via constructing 'stranger' identities, the immigrants of our data claim Greekness, on the one hand, and legitimize themselves as Canadian citizens on the other, while also distancing themselves from the Greeks living in Greece and the respective negative stereotypes.
\end{abstract}

Keywords: immigrants, transnationalism, stranger, positioning, hybridity 
Konstruowanie tożsamości hybrydowej „Obcego”. Przypadek greckich emigrantów w Kanadzie

\section{Streszczenie}

W naszym artykule stawiamy sobie za cel zbadanie różnych sposobów, na jakie greccy imigranci budują swoją tożsamość kulturową. Najnowsze podejścia do tożsamości kulturowej imigrantów wykorzystuja koncepcję transnacjonalizmu, w celu wyjaśnienia ich hybrydyczności i plynności. W pracy zamierzamy pokazać, że pojęcie "obcego" autorstwa Georga Simmela ([1908] 1971) można również odnieść do analizy i interpretacji tego typu transnarodowych tożsamości. W tym kontekście, bazując na teorii pozycjonowania Daviesa i Harré'go (1990), twierdzimy, iż nasi respondenci buduja hybrydowa tożsamość "obcego" głównie na dwa sposoby: i) jako jednocześnie Grecy i Kanadyjczycy, ii) jako Grecy, wtedy kiedy nie przebywaja w Grecji. Nasze dane zostaty zebrane w 15 czesściowo ustrukturyzowanych wywiadach badających imigranckie doświadczenia Greków, którzy wyemigrowali do Kanady w okresie od połowy lat czterdziestych do późnych lat siedemdziesiątych. Analiza skupia się na: (a) środkach dyskursywnych stosowanych przez respondentów w celu skonstruowania swojej hybrydowej tożsamości "obcego" oraz (b) konkretnych celach, które te środki spetniają. Badania wydaja się wskazywać, że hybrydowe samookreślenie osiaga się poprzez użycie: (a) zastrzeżenia: "Jestem / czuję się Grekiem, ale ...", (b) metafory, (c) krótkiego opowiadania i (d) mechanizmu naprawczego. Twierdzimy również, że poprzez budowanie tożsamości ,obcego” uwzględnieni w badaniu imigranci uznają się za Greków a jednocześnie za obywateli kanadyjskich, a przy tym dystansuja się od Greków żyjacych $w$ Grecji $i$ odpowiadajacych im negatywnych stereotypów.

Stowa kluczowe: imigranci, transnacjonalizm, obcy, pozycjonowanie, hybrydowość

\section{Introduction}

In reality, immigrants resemble trees:

their branches look towards the land they left from,

while their roots snuggle deeper and deeper into the land they arrived at.

(Kapllani 2006: 150)

Recent approaches to immigrants' cultural identities tend to employ the concept of transnationalism to account for their hybridity and fluidity, given that immigrants portray themselves as individuals with affiliations to (at least) two cultural communities: the community they originate in and the host one. However, such hybrid identities are not a recent phenomenon and have attracted scholarly interest for quite some time. Thus, we intend to show 
that Georg Simmel's ([1908] 1971, [1908] 2009) notion of the stranger is most relevant to the analysis and interpretation of such identities.

Our data consists of 15 semi-structured interviews exploring the immigrant experiences of Greeks who migrated to Canada from the mid-1940s until the late 1970s. Our analysis focuses on the hybrid self-positionings which try to strike a balance between the Greek and the Canadian identity, and which are particularly common in our data. More specifically, we examine (a) the discursive means the informants employ to construct the hybrid identity of the 'stranger', and (b) the specific purposes they fulfil. We argue that, via constructing such identities, the immigrants of our data claim Greekness, on the one hand, and legitimize themselves as Canadian citizens on the other, while also distancing themselves from the Greeks living in Greece and the respective negative stereotypes.

So, in section 2 we present the theoretical background of our study which involves the phenomenon of transnationalism and its relation to the identity of the 'stranger'. In section 3, we discuss positioning as our main analytical tool for exploring transnational/'stranger’ identities as well as the specific discursive resources to be focused upon later on. Then, we describe the Canadian context concerning immigration (section 4) and move on to the data presentation (section 5) and the data analysis (section 6). The analysis intends to bring to the surface informants' repertoire for constructing hybrid 'stranger' identities as well as their hesitant positionings towards such identities. Our discussion is rounded up in section 7 including the conclusions and some limitations of our study.

\section{Transnationalism and the identity of the 'stranger'}

Among the central characteristics of the emergent post-modern world are the processes of globalization, massive migration, and cross-cultural interactions. In this context, the discussion about language and human mobility has come to the forefront of sociolinguistic research (see among others Rampton 2008, Blommaert 2010, Pennycook and Otsuji 2015, Canagarajah 2017). The constant flows of people, products, ideas, and discourses have resulted in the coexistence of people from diverse cultural and linguistic backgrounds and, thus, to the transformation of sociopolitical structures. Blommaert (2010: 5) aptly observes that

the movement of people across space is [...] never a move across empty spaces. The spaces are always someone's space, and they are filled with norms, expectations, conceptions of what counts as proper and normal (indexical) language use and what does not count as such. 
Given the above, one of the topics which has attracted considerable scholarly attention is transnationalism (Basch et al. 1994; Vertovec 2004, 2009; Duff 2015). Transnationalism has been defined as "the processes by which immigrants forge and sustain simultaneous multistranded social relations that link together their societies of origin and settlement" (Basch et al. 1994: 5). In other words, immigrants are no longer seen as uprooted people who strive to assimilate in an inhospitable foreign environment, but as social agents who dynamically create transnational networks across host and home countries, shaping new cartographies of space and identity (De Fina 2016: 164-165; see also Smith and Guarnizo 1998; Faist 2000). In this sense, transnationalism challenges the dominant ideologies of the modern nation-state, which is based on, and promotes, homogeneity, stability, and the principle of 'one language-one nation'.

Over the last few decades, the discursive practices people employ to shape and negotiate their identities as members of transnational communities have become the focus of sociolinguistic research ascribing to the social constructionist paradigm. According to this paradigm, identities are not static and unchangeable properties of the self; their production, reproduction, transformation, and dismantling is achieved via discourse (Wodak et al. 1999: 3-4; see also Sarbin and Kitsuse 1994: 2, 8; Antaki and Widdicombe 1998; De Fina et al. 2006; Archakis and Tsakona 2012).

In this context, the notion of hybridity is frequently adopted to describe identity processes among deterritorialized people (De Fina 2016: 168). Hybridity emerges from the fact that transnational individuals may present themselves, and build their identities, as belonging either inside or outside certain spaces, in the center or in the periphery, in a blurred space which challenges traditional boundaries, or, as Bhabha (1994) would put it, in a "third space", where "the meaning and symbols of culture have no primordial unity or fixity; that even the same signs can be appropriated, translated, rehistoricized and read anew" (Bhabha 1994: 37). As a consequence, members of transnational communities may loose and eventually lose their sense of attachment to a physical territory. This means that linguocultural homogenization and homogeneity constitute unattainable goals as people redefine and mix linguistic and cultural resources and identities.

Despite the strong interconnection between hybridity, transnationalism, and post-modern mobility as part of globalization processes, hybridity is not at all a recent phenomenon and has attracted scholarly attention for quite some time now. Among others, the sociologist Georg 
Simmel ([1908] 1971, [1908] 2009) attempts to account for such hybrid identities by proposing the "sociological form of the 'stranger"' ([1908] 1971: 143). His account of the 'stranger', not unlike the modern accounts of transnationalism, is based on what he calls the "locality principle" or "membership by place" (Simmel [1908] 2009: 606), namely the classification of individuals on the basis of spatial delimitations. The 'stranger' moves across spatial boundaries, but is not in constant movement:

The stranger will thus not be considered here in the usual sense of the term, as the wanderer who comes today and goes tomorrow, but rather as the man who comes today and stays tomorrow - the potential wanderer, so to speak, who, although he has gone no further, has not quite got over the freedom of coming and going. He is fixed within a certain spatial circle-or within a group whose boundaries are analogous to spatial boundaries- but his position within it is fundamentally affected by the fact that he does not belong in it initially and that he brings qualities into it that are not, and cannot be, indigenous to it.

(Simmel [1908] 1971: 143)

In other words, even though contemporary approaches to transnationalism and mobility suggest that individuals are in a permanent state of movement across linguocultural and sociopolitical boundaries, Simmel's account refers to individuals who move from one place to another but at some point they settle down and become 'strangers' in a place where they are "no owner[s] of land - land not only in the physical sense but also metaphorically as a vital substance which is fixed, if not in space, then at least in an ideal position within the social environment" (Simmel [1908] 1971: 144). It should be noted here that, after our informants left Greece, they have settled in Canada where they have lived ever since then. Thus, they conform more to Simmel's ([1908] 1971, [1908] 2009) account of the 'stranger' than to recent sociolinguistic accounts of transnational mobile individuals who are often perceived as constantly on the move.

In Simmel's view, the 'stranger' becomes a member of the host community or group, thus being "near and far at the same time" ([1908] 1971: 148, emphasis in the original). This duality grants him/her with 'a distinctly 'objective' attitude, an attitude that does not signify mere detachment and nonparticipation, but is a distinct structure composed of remoteness and nearness, indifference and involvement" (Simmel [1908] 1971: 145). That is to say, such "objectivity" does not mean lack of interest or participation, but on the contrary it entails a positive kind of participation allowing the 'stranger' to understand, evaluate, and act without being bound by the same commitments and prejudices that may affect, or be imposed on, local people (Simmel [1908] 1971: 145-146). To use more recent terminology, the 'stranger' may 
adopt a more critical perspective on things and be considered an "especially perceptive member of society" (De Korne et al. 2007: 296, our emphasis), as s/he strives to strike a balance between the two cultures. As De Korne et al. (2007: 290) suggest, "the main characteristics of being bicultural in their experience include heightened self-awareness and understanding of difference, and a potential for critical objective perspective on their environment" (our emphasis).

It is exactly this combination of detachment and attachment, confrontation and membership, indifference and involvement, remoteness and nearness that we find appealing and useful for the purposes of the present study. Such a combination is, in our view, most compatible with, and complementary to, more recent approaches emphasizing the hybridity of the identities constructed by transnational individuals (see also De Korne et al. 2007). In addition, even though Simmel's conceptualization mostly refers to the 'stranger's' attitudes towards the host community, here we will demonstrate that this combination of nearness and remoteness may involve both the host community and the community of origin. Thus, we will try to show the "near-paradoxical balance that is inherent to bicultural identity" (De Korne et al. 2007: 295).

In the next section, in order to discuss the discursive means through which speakers build their hybrid identities as 'strangers', we will draw on Davies and Harré's (1990) notion of positioning and trace the specific discursive forms positioning may take in the data under scrutiny.

\section{Positioning and its discursive means}

The complex character of transnational identities has become a fertile area of research, which we will approach through the concept of positioning put forward by scholars such as Davies and Harré (1990), Harré and van Langenhove (1991, 1999), and Deppermann (2013). Positioning concerns attitudes, evaluations, and points of view emerging through linguistic and interactional resources:

Once having taken up a particular position as one's own, a person inevitably sees the world from the vantage point of that position and in terms of the particular images, metaphors, story lines and concepts which are made relevant within the particular discursive practice in which they are positioned.

(Davies and Harré 1990: 46, our emphasis) 
Since positioning is interactionally negotiated (Harré and van Langenhove 1999: 2-4), individuals may employ various, even contradictory, subject positions as well as question and resist other-positionings (Malhi et al. 2009). In this sense, positioning seems most suitable for analyzing ambiguous identities such as the 'stranger's' one, as defined by Simmel ([1908] 1971, [1908] 2009; see section 2).

Positioning may involve a variety of discursive means. In the data under scrutiny, the following ones are commonly attested:

1. The disclaimer I am/feel Greek but...: Studies on positioning have shown that individuals may employ three kinds of discourses in order to position themselves in terms of cultural identities: (a) the discourse of 'being', which concerns self-definition regarding demographical characteristics such as place of birth; (b) the discourse of 'doing', which concerns typical practices of the culture such as speaking a language; and (c) the discourse of 'feeling', which comprises internal and private beliefs and feelings of belonging to a certain group (Verkuyten and deWolf 2002, Malhi et al. 2009, van Bochove et al. 2015). In our analysis, we mostly concentrate on discourses of 'being' and 'feeling', as the discourse of 'doing' is less often attested in our data. More specifically, our informants project a specific cultural identification for themselves, which they partly mitigate via a but sentence. ${ }^{1}$

2. Metaphors: As Demjén and Semino (2016) point out, metaphor "involves the perception of similarities or correspondences between unlike entities and processes, so that we can see, experience, think and communicate about one thing in terms of another". In this sense, metaphors are not merely figures of speech embellishing discourse, but shape the ways we make sense of our experiences and hence act (see also Lakoff and Johnson 1980; Kövecses 2005).

3. Small stories: Storytelling as an everyday practice constitutes a fertile locus where interlocutors construct identities (Bamberg 1997; Georgakopoulou 1997, 2007, De Fina and Georgakopoulou 2011; Archakis and Tsakona 2012). We are particularly interested in small stories characterized by small length and fluidity and referring to future or hypothetical events, to shared/known events, to recent or ongoing events, etc. (Georgakopoulou 2007). Small stories underscore the "multiplicity, fragmentation, 
context-specificity and performativity of our communication practices" (Georgakopoulou 2015: 257).

4. Repair mechanisms: Within Conversation Analysis, repair "refers to the processes available to the speaker through which they can deal with problems or difficulties which emerge in talk" (Schegloff et al. 1977). Such difficulties are framed with pauses, cuttings, prolongation of sounds (see also Schegloff et al. 1977: 367). The same function may be fulfilled by evaluative phrases, such as the phrase this is difficult to answer..., which is attested in the data examined here. This phrase shows individuals' hesitation or reluctance to reply and/or position themselves in a straightforward manner and hence may function as a preface to hybrid identities. Problems and difficulties emerging in talk are usually resolved though reformulation, namely a process of textual re-interpretation via which speakers re-elaborate a fragment of previous discourse and present it in a different way (Cuenca and Bach 2007: 149, Karachaliou and Archakis 2015).

All these discursive strategies bring to the surface our informants' efforts to construct hybrid identities oscillating between Greekness and Canadian-ness and combining elements of both cultures. They appear to exhibit difficulty and/or reluctance to position themselves as individuals with unicultural/monocultural identities, even though they participate in a context where such identities could be more or less expected, namely in interviews conducted by Greek researchers in the Greek language (see section 5 and the limitations of the study in section 6). It appears that resorting to the hybrid 'stranger' identity helps them to justify their tendency to refrain from a monocultural Greek or Canadian identity.

In the following section, we offer an account of the social and historical context where such hybrid Greek-Canadian identities emerge(d).

\section{Canada as a host country for Greek immigrants}

Before WWII, the Greeks of Canada were estimated about 12,000 (Constantinidis 2004). In the post-WWII era, the political, social and economic upheaval in Greece (including the occupation of Greece by the Axis Powers, 1941-1945, and the Greek Civil War, 1946-1949) led many Greeks to immigration, which reached its peak between the 1950s and the 1970s. 
Since the Canadian economy was rapidly growing and needed labor in the postwar period, Canadian immigration policies "became more flexible and allowed the invitation and sponsorship of family members [of immigrants already settled in Canada] and other relatives" (Kalogeropoulou 2015: 16-20). As a result, more than 110,000 Greeks migrated to Canada. ${ }^{2}$

The majority of Greek immigrants came from rural and semi-urban areas, were unskilled and illiterate, and dreamt of returning to their homeland in the future (Gavaki 2003: 63; Constantinidis 2004). Most of the first immigrants settled in Montreal and Toronto, while communities were also created in Ottawa, Quebec City, Halifax, Edmonton, and Vancouver (Chimbos 1999; see also Tamis and Gavaki 2002; Aravossitas 2016). In order to maintain their bonds with their country of origin, Greek immigrants participated in family gatherings, celebrations, and attended Greek Orthodox churches and schools, which gradually led to the formation of Greek communities.

While Canada is officially a bilingual country, its cultural mosaic comprises over 50 indigenous languages and many immigrant languages (Patrick 2010). Canada's language policy strongly supports linguistic diversity via laws such as the Official Languages Act of 1969 (which recognized French and English as official Canadian languages) and the Multiculturalism Policy of 1971 (which allows immigrants to preserve their own cultures and languages). Multiculturalism in Canada can be best formulated in the following terms:

immigrants should integrate both culturally and linguistically into Canada (for example by acquiring Canadian cultural practices and learning to speak English or French well), but they should not have to give up their own cultural practices and languages in order to do so.

(Liebscher and Dailey-O'Cain 2013: 7)

It therefore seems that the sociopolitical conditions in postwar Canada favored the maintenance of immigrants' heritage languages and cultures to a certain extent, since immigrants were simultaneously expected to assimilate (at least partly) to the local cultures and languages so as to become integrated to Canadian society. It is in this context that the Greek immigrants examined here developed ambiguous and hybrid identities as Greek 'strangers' in Canada.

\section{The data of the study}

As already mentioned, this study is part of a large-scale research project which explores the immigrant experiences of Greeks who migrated to Canada from the mid-1940s until the late 
1970s. For the purposes of the project, semi-structured interviews were conducted, involving three domains of interest: (a) the origin of the informant and their migration journey, (b) their arrival and settlement, and (c) their integration. Since we are interested in the construction and negotiation of transnational identities, we place emphasis on the discursive practices our informants employ while answering the question "Do you feel (more) Greek and/or Canadian?" pertaining to the integration process (see [c] above).

The data collected consists of more than 100 interviews. The interviewees migrated to Canada during the period 1956-1974. At the time of their migration, their age ranged from 12 to 29 years old. When the recordings took place, the interviewees were 55-85 years old. Their years of residency in Canada varied from 40 to 60 years. The interviews were conducted in different cities such as Vancouver, Victoria, Edmonton, Montreal and Toronto. The subcorpus examined here includes 15 interviews; eleven informants were male and four female. The present discussion will focus on the construction of hybrid 'stranger' identities, as these concern the majority of our data (10 out of 15 interviews).

\section{Data analysis}

Most of our informants chose to position themselves through hybrid identities allowing them to portray themselves as 'strangers' in Simmel's ([1908] 1971) conceptualization of the term, in the present case as both Greeks and Canadians or as feeling Greek but not when in Greece. The data reveals that, in order to construct such self-positionings, the participants of our study rely on a variety of discursive resources: (a) the disclaimer I am/feel Greek but..., (b) metaphors, (c) small stories, and (d) repair mechanisms, either separately or combined. The discourses of 'being' and 'feeling' are also used in combination with these resources.

\subsection{The disclaimer I am/feel Greek but...}

With this disclaimer the informants initially position themselves as Greeks and then complement their self-identification with a sentence introduced with but. Thus, they manage to construct hybrid identities: ${ }^{3}$

\section{Extract 1}

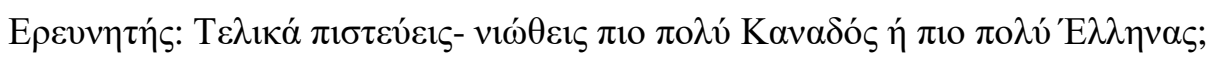

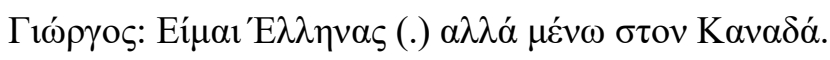


Researcher: Finally, do you believe- do you feel more Canadian or more Greek?

George: I am Greek (.) but I live in Canada.

Although the interviewer's question is oriented towards the discourse of 'feeling', George claims his identity through the discourse of 'being', presenting his Greekness as a permanent property (I am Greek). After a short pause, he resorts to the discourse of 'doing' and to the but disclaimer to mitigate his initial positioning (but I live in Canada), thus bringing his Canadianness to the surface. Through this hybrid self-positioning George suggests that Greekness is a stable and simultaneously deterritorialized identity (one can be/remains Greek even when living outside Greece) and co-exists with Canadian-ness. In other words, he portrays himself as a Greek 'stranger' in Canada.

In the following extract, Theodore at first positions himself as Greek through the discourse of 'feeling' and then refers to the privileges of Canadian citizenship:

\section{Extract 2}

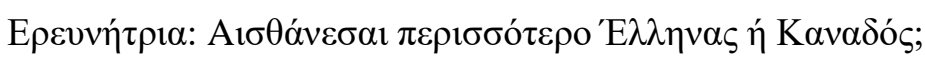

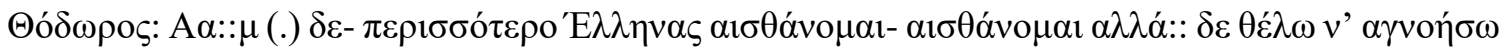

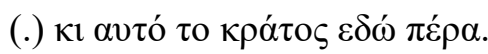

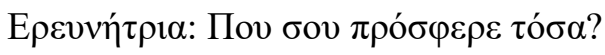

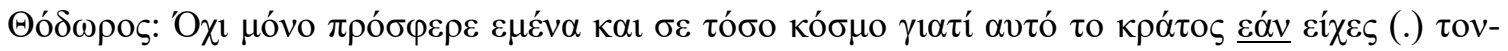

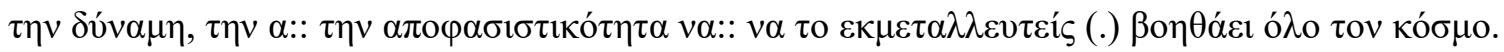

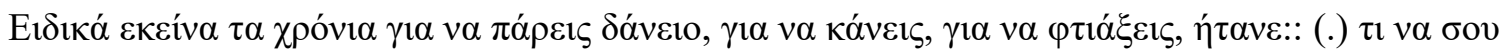

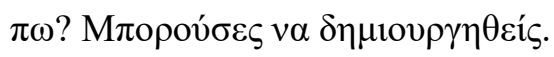

Researcher: Do you feel more Greek or Canadian?

Theodore: Hu::h (.) I don't- I feel more Greek I feel- bu::t I do not want to ignore (.) this state here [i.e. Canada].

Researcher: Which offered you so many things?

Theodore: Not only did it offer me and so many people [so many things] because this state if you had (.) the- the strength, the de- the determination to:: to take advantage of it (.) it helps all the people. Especially those years you could get a loan, do [things], make, it wa::s (.) what can I say? You could make yourself.

Theodore first positions himself as feeling more Greek and then through the but disclaimer expresses his intention to refer to the Canadian state (bu::t I do not want to ignore (.) this state 
here). In what follows, he provides justification/argumentation for introducing Canada to his construction of identity (Not only did it offer me and so many people [so many things] because this state if you had (.) the-the strength, the de-the determination to:: to take advantage of it (.) it helps all the people): the financial support and the efficiency of the Canadian state are highlighted via the evaluative climax including the recipients of Canadian aid (not only me $\rightarrow$ so many people $\rightarrow$ all the people). To strengthen his positioning, Theodore recalls the Canadian support when he first arrived at the host country (Especially those years you could get a loan, do [things], make): Canada provided/s the appropriate conditions and opportunities for the newcomers to "make themselves". Thus, via the disclaimer and the following justification, Theodore positions himself as emotionally attached to the Greek identity and as a legitimate and grateful member of the Canadian state. Simultaneously, he adopts the 'objective' perspective of the 'stranger' to refer to Canada as a generous and helpful state for outsiders or newcomers.

In extract 3, the informant relies on the discourse of 'being' to promote a hybrid Greek and Canadian identity:

\section{Extract 3}

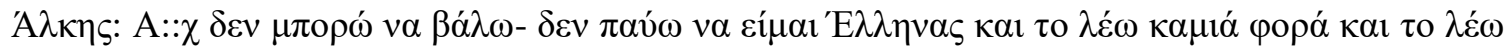

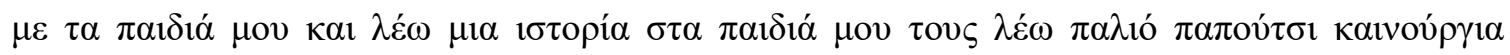

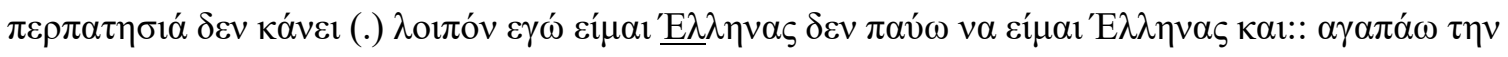

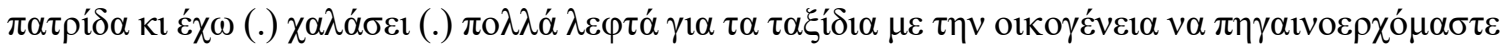

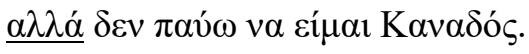

\footnotetext{
Alkis: A::hh I cannot put- I don't stop being Greek and I say it sometimes and I say it with my children and I tell a story to my children I tell them an old shoe doesn't give a new way of walking (.) so I am Greek I don't stop being Greek a::nd I love the homeland and I have (.) spent (.) a lot of money on trips with the family to come and go but I don't stop being Canadian.
}

After having difficulty in uttering an answer (A::hh I cannot put-; see also section 6.4), Alkis uses the discourse of 'being' to claim his Greek identity (I don't stop being Greek). To strengthen his claim, he narrates a small story in which he portrays himself as telling his children a Greek proverb, thus reinforcing the validity of his positioning as Greek (see section 6.3 on the use of small stories as argumentation). Then, he once again relies on (a) the discourse of 'being' twice (I am Greek I don't stop being Greek) to emphasize that the Greek identity is 
a permanent feature of his identity, and (b) the discourse of 'feeling' (I love the homeland) to express his emotional attachment to Greece. In addition, his self-positioning as Greek is strengthened by the frequent trips to Greece with his family. After highlighting the Greek aspect of his identity, Alkis uses the disclaimer with but to introduce the 'being' discourse for his Canadian identity (I don't stop being Canadian), which is also presented as a permanent property of his and creates a structural parallelism with the expression of his Greek selfpositioning (I don't stop being Greek). Although he elaborates on the Greek identity and feels that he has to prove or justify it (via storytelling to his children, expressing love for the homeland, and making trips to the country of origin), he complements this identity act with the but disclaimer, which brings his Canadian-ness to the forefront. Thus, he self-identifies as a 'stranger' with dual (Greek and Canadian) affiliation.

In sum, our informants employ but disclaimers to position themselves as 'strangers' feeling close to Canada (as Canadians) and far from it (as Greeks) at the same time. The fact that they often justify such a near-paradoxical self-positioning (in examples [2-3]) indicates that, from their point of view, monocultural identities (Greek or Canadian) rather than hybrid ones are perceived as expected in the specific context (i.e. research interviews in Greek; see section 5). Their reluctance to ignore their own warm feelings and gratitude towards the Canadian state lead them to compromise their initial, powerful claims to a Greek identity.

\subsection{Metaphors}

In this section, we examine cases in which informants rely on metaphors to position themselves. Metaphors are used to make their hybrid 'stranger' identities easier to understand. In extract 4, Nasos uses the but disclaimer and at the same time resorts to a metaphor to bring his Canadian identity to the surface:

\section{Extract 4}

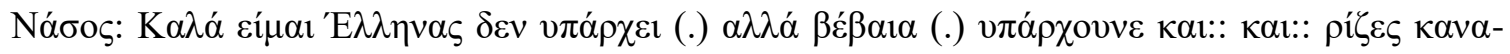

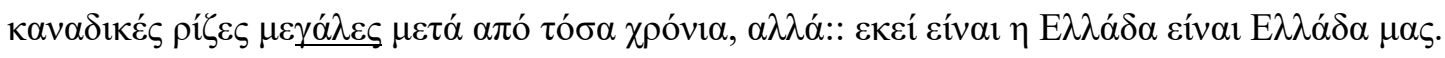

Nasos: Well I am Greek there is not (.) but certainly (.) there are also:: also:: roots Cana- Canadian roots, big [roots] after so many years, bu::t it is there Greece is our Greece.

Nasos first introduces the discourse of 'being' Greek as an indisputable feature (well I am Greek there is not) and then via the but disclaimer draws upon the 'roots' metaphor. The 'roots' 
metaphor is frequently used to associate immigrants' communities with their homelands and cultural heritage, since roots are considered a vital part of the plant (Malhi et al. 2009: 269). Notably, Nasos reverses the 'roots' metaphor to highlight his Canadian-ness as an essential part of his identity (but certainly (.) there are also:: also:: roots Cana-Canadian roots, big [roots]). His claim to the Canadian identity is justified, and therefore legitimized, by the years of residency in Canada (after so many years). It is interesting to note here that the root metaphor is not used for the country of origin (i.e. Greece) but for the host one (i.e. Canada), thus reversing its conventional use, according to which immigrants feel uprooted and hence emotionally damaged when removed from their 'native soil' (Malhi et al. 2009: 269).

The prominent position Nasos attributes to his Greek identity results in the second use of the but disclaimer (bu::t it is there Greece is our Greece). In order to position himself as member of the Greek community and to exhibit his strong bonds with his homeland, he describes himself and other fellow immigrants as "owners" of Greece via the use of the possessive pronoun our. As already mentioned (in section 2), the 'stranger' is not a landowner in his/her place of residence, either literally or metaphorically. This aspect of the 'stranger' identity is evoked here: as a person of Greek origin, Nasos feels that he metaphorically "owns" Greece, while he does not "own" Canada, where he has lived most of his life.

In the following extract, Antonis also uses a metaphor to highlight his 'stranger' identity. In fact, Antonis here combines all the discursive means traced in our data:

\section{Extract 5}

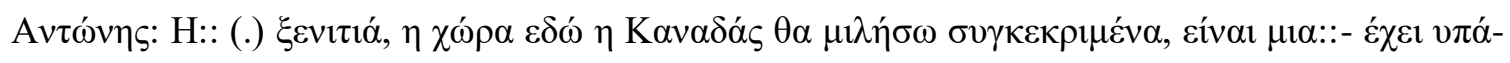

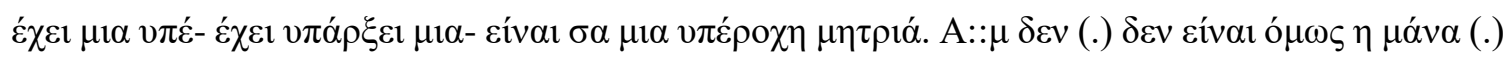

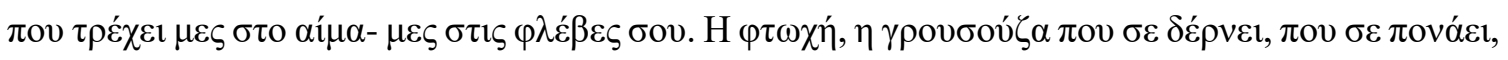

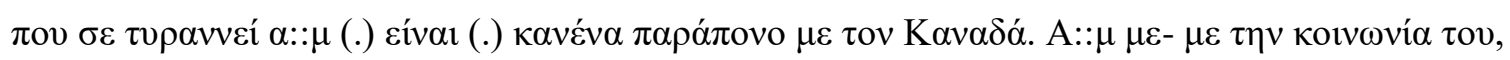

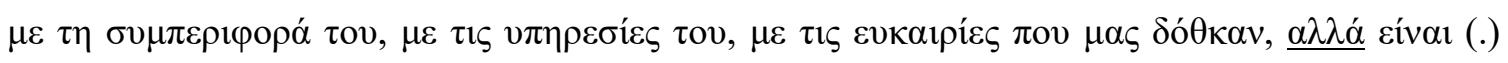
$\mu \eta \tau \rho i \alpha ́$.

Antonis: The:: (.) foreign land, the country here Canada, to be specific, is a::- has been a- has a wonder- has been a- it's like a wonderful stepmother. Hu::m it's not (.) but it is not the mother (.) that runs in the blood- through your veins. [It is] the poor, the jinx, that beats you, that hurts you, that oppresses you hu::m (.) it is (.) no complaints about Canada. Hu::m with its society, with its behavior, with its services, with the opportunities given to us, yet it is (.) a stepmother. 
Antonis' answer revolves around the 'mother' and 'stepmother' metaphors and the opposition between them. He attributes to Canada the role of a wonderful, caring, and flawless stepmother who provides prosperity, security, and welfare to her children (no complaints about Canada. Hu::m with its society, with its behavior, with its services, with the opportunities given to us). By contrast, Greece is metaphorically represented as a poor and jinx mother who abuses, hurts, and oppresses her children (the mother (.) that runs in the blood-through your veins. [It is] the poor, the jinx, that beats you, that hurts you, that oppresses you). Interestingly, the stereotype of the wicked stepmother is here reversed. Despite the negative feelings and experiences related to Greece, on the one hand, and the positive attitudes towards Canada, on the other, Antonis clearly implies that the emotional bond with mother-Greece is much stronger than the one with the stepmother-Canada. Yet, he is grateful to Canada. In other words, Antonis presents himself as originating in mother-Greece and raised by stepmother-Canada, thus showing a 'stranger's' detachment and attachment to both countries.

The metaphors analyzed here appear to be exploited by the informants to position themselves as 'strangers'. They allow them to express their feelings of both detachment and attachment, remoteness and nearness not only towards the host country as Simmel (1971/1908; see section 2) suggests, but also towards the country of origin. It should also be noted that portraying the motherland in a rather negative manner and the host country in a positive manner does not come easily to the informant in example [5] (see the pauses, cuttings, and reformulations: The:: (.) foreign lands, the country here Canada, to be specific, is a::- has been a- has a wonder.- has been a- it's like a wonderful stepmother.). Such an evaluation reversal and hybrid identity are expressed with much hesitation and difficulty from his part.

\subsection{Small stories}

Here we examine extracts where the participants of the project embed small stories in their answers to support their self-positionings:

\section{Extract 6}

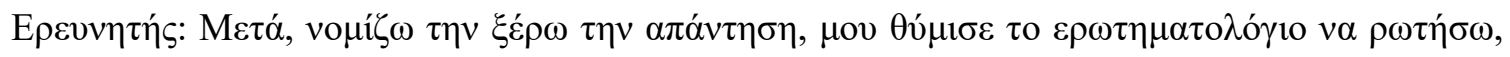

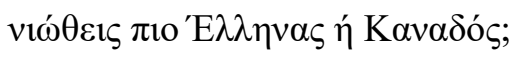

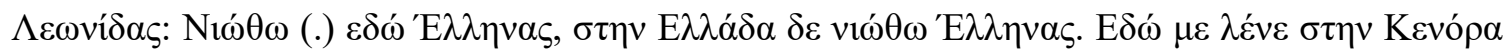

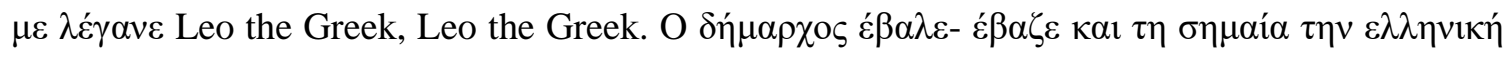

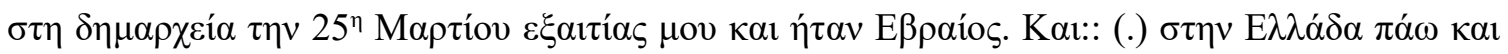

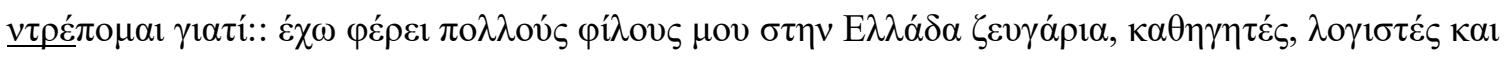




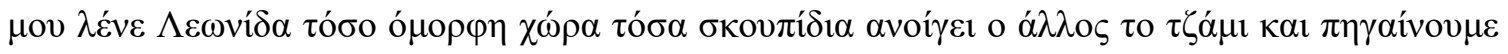

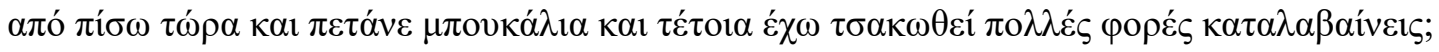

Researcher: Then, I think I know the answer, the questionnaire reminded me to ask, do you feel more Greek or Canadian?

Leonidas: I feel (.) Greek here, in Greece I don't feel Greek. Here they call me, in Kenora ${ }^{4}$ they called me Leo the Greek, Leo the Greek. The mayor put- used to put the Greek flag at the town hall on March $25^{\text {th5 }}$ because of me though he was Jewish. A:::nd (.) I go to Greece and I feel shame becau::se I have brought many friends of mine to Greece, couples, professors, accountants and they tell me Leonidas such a beautiful country so much garbage someone opens the car window and we are following [the car] from behind now and they throw bottles [out of the car window] and things like that I have quarreled many times, do you get it?

In extract 6, Leonidas positions himself as feeling Greek in Canada, but not in Greece. His Greekness is constructed as inconsistent within the Greek territory, but as compatible with the Canadian territory. To support his claim, he recounts two small stories. In the first one, he represents the Jewish mayor of Kenora hanging a Greek flag at the town hall for Leonidas' sake, in order to celebrate the Greek Independence Day on March $25^{\text {th }}$, thus highlighting the value attributed to being Greek in Canada. This incident is used to justify why he feels Greek in Canada. The second story accounts for his embarrassment for, and rejection of, the Greek identity. The protagonists-friends of Leonidas' appear to recognize the beauty of his homeland, but express their discomfort with excessive littering. Through this narrative he positions himself as a person who constantly quarrels with other Greeks about issues of public hygiene. This hybrid identity allows Leonidas to claim Greekness and, at the same time, distance himself from Greeks living in Greece and the respective negative stereotypes. Leonidas thus resorts to two small stories with an argumentative function to construct the identity of the 'stranger', which simultaneously allows him to offer an 'objective' and critical account of such his choices. Interestingly, his 'objectivity' is not used here to evaluate the host country (as proposed in Simmel's 1971/1908 description of the 'stranger's' features; see section 2 and example [5]), but to evaluate his country of origin as not conforming to his current standards (while the host country does).

In extract 7 (see also section 5.1), Alkis, after self-positioning as Greek, tells a story justifying his choice:

Extract 7

www.journal.tertium.edu.pl 


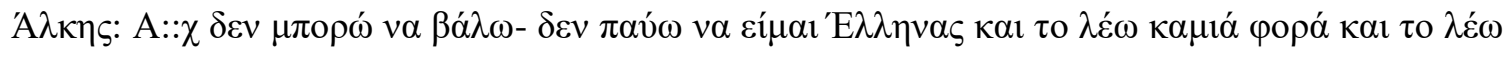

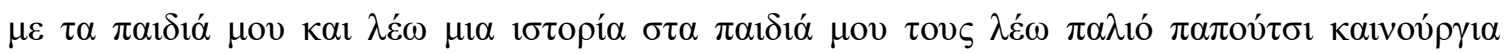

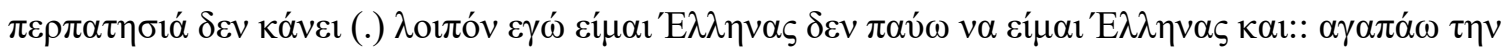

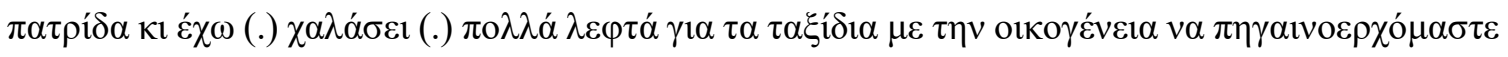

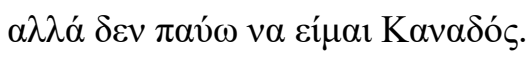

Alkis: A::hh I cannot put- I don't stop being Greek and I say it sometimes and I say it with my children and I tell a story to my children I tell them an old shoe doesn't give a new way of walking (.) so I am Greek I don't stop being Greek a::nd I love the homeland and I have (.) spent (.) a lot of money on trips with the family to come and go but I don't stop being Canadian.

In his small story, Alkis presents himself as the protagonist in an incident where he tells his children a Greek saying (I tell a story to my children I tell them an old shoe doesn't give a new way of walking). He self-identifies as a Greek father reciting Greek proverbs to his children, yet his Canadian-ness is not ignored. The hybrid identity of the 'stranger' is thus constructed (see also the analysis in section 6.1).

In sum, the small stories inserted in the responses of our informants are meant to construct, at first, a Greek identity and, later on, to deny it and replace it with more complicated positionings also including Canadian-ness. Greekness is usually perceived as a stable, unchangeable property of the individuals, hence informants feel the need to justify their hybrid positionings through small stories. Our 'stranger' informants manage to express their ambivalent feelings of detachment and attachment mostly towards Greece and, less explicitly, towards Canada.

\subsection{Repair mechanisms}

In this section, we investigate the repair mechanisms accompanying self-identifications showing informants' difficulties in providing a straightforward answer. First of all, informants may explicitly admit their difficulty in choosing between the two cultural identities and then display their strong bonds to both countries:

\section{Extract 8}

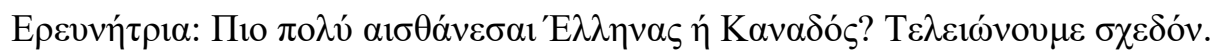

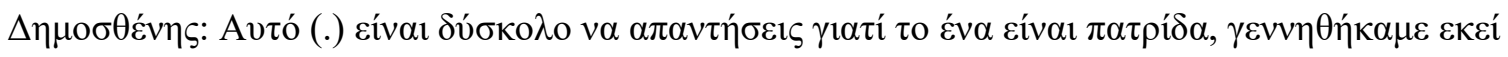

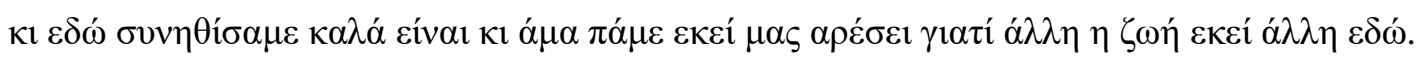


Researcher: Do you feel more Greek or Canadian? We are almost finished.

Dimosthenis: This (.) is difficult to answer because the one is homeland, we were born there, we got used to [living] here, it is nice and if we go there we like life there because life here is different.

Dimosthenis first expresses his difficulty to position himself as either Canadian or Greek. To account for this difficulty, he presents Greece as his homeland and Canada as the place where he got used to living. Interestingly, he does not speak for himself as an individual but as a member of a collective group (we were born there, we got used to [living] here, if we go there we like life there), thus indicating that he shares this ambivalent identity with other people. Then, he expresses his positive attitudes towards both the Canadian way of living (it is nice) and the Greek one (and if we go there we like life there because life here is different). The initial evaluation encoded through the phrase this is difficult to answer indicates hesitation and allows Dimosthenis not to choose between one identity or the other while being interviewed in Greek by a Greek researcher (see section 5). Instead, he creates a hybrid 'stranger' identity whereby Greekness and Canadian-ness are both embraced and his hesitation forces him to explain his choice.

In the majority of our extracts, repair mechanisms such as pauses, cuttings, and reformulations appear at the beginning of the answers including informants' positionings:

\section{Extract 9}

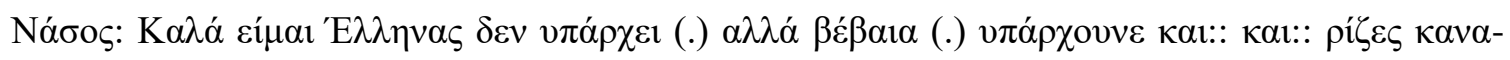

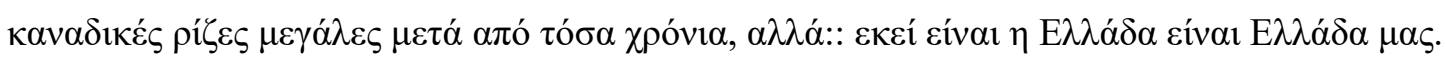

Nasos: Well I am Greek there is not (.) but certainly (.) there are also:: also:: roots Cana- Canadian roots, big [roots] after so many years, bu::t it is there Greece is our Greece.

\section{Extract 10}

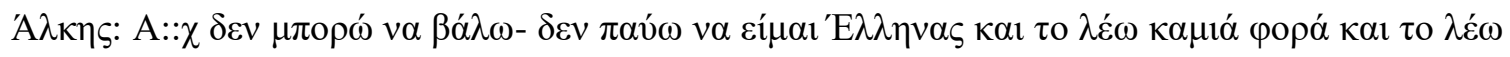

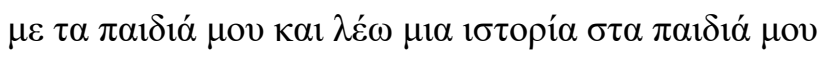

Alkis: A::hh I cannot put- I don’t stop being Greek and I say it sometimes and I say it with my children and I tell a story to my children

\section{Extract 11}




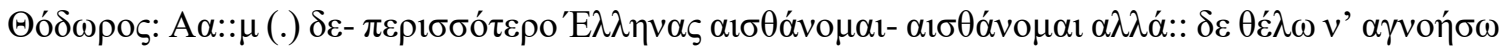

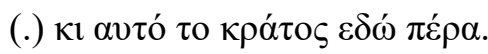

Theodore: Hu::h (.) I don't- I feel- I feel more Greek bu::t I do not want to ignore (.) this state here [i.e. Canada].

As the above extracts illustrate, before uttering a straightforward self-positioning through discourses of 'being' or 'feeling', the participants tend to use pauses, hesitations, and cuttings. Thus, they seem to express their difficulty in finding what they seem to perceive as the 'right' answer, implying that hybrid 'stranger' identities are difficult to be described at once (see also examples [2-5]).

In addition, reformulations may be used for re-positionings, namely to correct the initial self-identification:

\section{Extract 12}

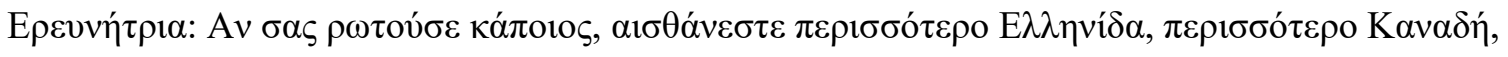
$\tau \imath \theta \alpha \alpha \pi \alpha \nu \tau \circ \tilde{\sigma} \sigma \tau \varepsilon$

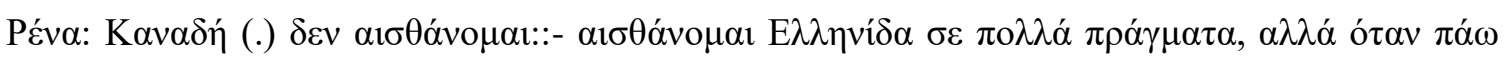

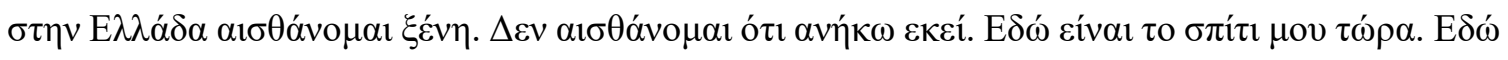
$\alpha \vee \eta ́ \kappa \omega$.

Researcher: If one asked you, do you feel more Greek, more Canadian, what would you answer? Rena: Canadian (.) I do not fee::I- I feel Greek in many ways, but when I go to Greece I feel like a foreigner. I do not feel that I belong there. Here is my home now. I belong here.

Initially, and without hesitation, Rena positions herself as feeling Canadian. Then, she goes on to clarify her self-identification (I do not fee::l), but decides to reformulate her utterance. Via using the 'feeling Greek' discourse (I feel Greek in many ways) and the but disclaimer, she paves the way for the construction of a deterritorialized identity (but when I go to Greece Ifeel like a foreigner. I do not feel that I belong there). Finally, she describes Canada as her home, where she belongs (Here is my home now. I belong here). Reformulation enables Rena to reposition herself and to construct a 'stranger' identity.

The repair mechanisms employed by the informants underline their oscillation between the two cultural identities and their hesitation to ascribe to only one of them. At the same time, they indicate that the construction of hybrid 'stranger' identities is perceived as something 
rather unconventional, “near-paradoxical” (in De Korne et al.'s 2007: 295 terms; see section 2) or at least unexpected in this context, hence it needs to be further justified.

\section{Conclusion}

The constant flows of people, products, and ideas in the postmodern era have radically transformed contemporary societies and states, as people from different cultural and linguistic backgrounds co-exist and interact in them. Despite the geographical distance, members of transnational communities often have the opportunity to preserve the ties with their country of origin, thus experiencing cultural and linguistic hybridity. Such hybridity is also clearly reflected in the identity of the 'stranger'. From a sociological perspective, Simmel ([1908] 1971, [1908] 2009) describes as 'strangers' those individuals who move across spatial borders and settle in new places, thus developing an ambivalent detachment/attachment, remoteness/nearness attitude towards these places and their people. In this context, the central question of our research revolves around the multiple self-positionings of Greeks who migrated to Canada during the period 1945-1975, and the various discursive means they employ to construct and negotiate their detachment/attachment to both Canada and Greece.

Our analysis has shown that the majority of our informants build hybrid 'stranger' identities for themselves. Via complex self-positionings, transnational individuals combine Greekness and Canadian-ness in creative ways. They draw on the discourses of 'being' and 'feeling' which are combined with (a) the disclaimer I am/feel Greek but..., (b) metaphors, (c) small stories, (d) the evaluative phrase this is difficult to answer..., and (e) repair mechanisms.

More specifically, the disclaimer I am/feel Greek but... enables the informants to both claim Greekness and legitimize themselves as members of the host country due to factors such as residency and upbringing (see examples [1-4], [7], [12]). This discursive strategy also brings to the surface aspects of a deterritorialized identity: one can remain Greek even after migrating to Canada. Metaphors are employed to facilitate our understanding of the complex feelings towards to host country and the country of origin (examples [4-5]). Small stories function as argumentative devices accounting for the hybridity of self-positionings and allow speakers to express their attachment to the Greek cultural heritage, on the one hand, and to distance themselves from Greeks living in Greece and the ensuing negative stereotypes, on the other (see examples [6-7]). Via the evaluative phrase this is difficult to answer..., informants avoid claiming a monocultural identity and exhibit their preference for both cultural identities 
(example 8). Finally, repair mechanisms indicate informants' difficulty and reluctance to articulate a 'stranger' identity in a straightforward manner (examples [2-12]).

Simmel ([1908] 1971: 146) suggests that 'strangers' develop an "objective" or "bird's-eye view" perspective on issues related to the host community, enabling them to participate in local affairs in a more detached manner than local individuals usually do (see section 2). Such “objectivity" is illustrated when the 'strangers' of our data express their gratitude and warm feelings towards the host country (examples [2], [4-6], [12]), while it also surfaces when they wish to offer negative evaluations of their country of origin (examples [5-6]). Despite such an “objective" view, Greek 'strangers' living in Canada still feel that they "own" their homeland and not their place of residence (example [4]), thus confirming Simmel's ([1908] 1971: 144) observation that the 'stranger' is not-literally or metaphorically- a landowner in the host community. Such contradictory feelings and positionings indeed capture what De Korne et al. (2007: 305) call "the see-saw phenomenon of interculturalism and bicultural identification". And Simmel's sociological type of the 'stranger' turns out to be a most suitable tool for accounting for hybrid transnational identities.

The discursive means identified and examined here often reflect that our informants are not exactly 'comfortable' with such hybridity: they seem to feel that they need to justify the identity of the 'stranger', so they employ repair mechanisms and various forms of justifications (examples [2-12]). Still, our informants do not use the terms Greek-Canadian or CanadianGreek, even though such terms are not uncommon in Greek. Their reluctance may result from one of the limitations of the present study: the informants were interviewed in Canada, but in Greek by Greek and/or Greek-speaking researchers, and they were aware that the interviews placed emphasis on their stories and experiences as Greek immigrants settled in Canada. In this context, they may choose accommodate to (what they assume are) their interlocutors' expectations concerning the maintenance/construction of the Greek identity.

Our final observation involves an overall positive account of hybridity and transnational/‘stranger’ identities. As De Korne et al. (2007: 305) suggest,

[t]he phenomenon of identification with multiple cultures is increasing, and yet bicultural individuals are still subject to labels that identify them as non-mainstream group, and many of these labels may carry negative connotations. Foreigner, newcomer, alien, stranger, minority there is a long tradition of placing immigrants outside the domain of cultural legitimacy, and of diminishing the status of those who are deemed to have only partial claim to cultural belonging.

(De Korne et al. 2007: 305) 
The theoretical and analytical frameworks adopted here have enabled us to bring to the surface hybrid cultural identifications which have been stigmatized in the past, but tend to become increasingly visible and accepted nowadays. More research is undoubtedly necessary to reveal more discursive strategies employed for self-identifications that may stem from 'strangers', but will thus no longer be 'strange' to us.

\section{Notes}

${ }^{1}$ For hybrid identities built via similar disclaimers, see van Dijk (1992), Archakis (2014, 2018), Archakis and Tsakona $(2016,2018)$.

${ }^{2}$ In 1967 alone, the number rose to 10,650, as many fled Greece to avoid the political turmoil of the Greek military junta (1967-1974).

${ }^{3}$ All interviewees' names are pseudonyms for ethical reasons. The following transcription conventions are used:

? upward intonation

(.) micropause

$\underline{\text { XzX }}$ emphasis

- self repair

:: sound prolongation

. stopping fall in tone

${ }^{4}$ Kenora is a city situated in Northwestern Ontario, Canada, close to the Manitoba boundary.

${ }^{5}$ The Greek independence from the Ottoman Empire is celebrated on March $25^{\text {th }}$, as this is the date the revolution against the Ottomans officially began back in 1821 .

\section{References}

Antaki, Charles, Sue Widdicombe (1998) "Identity as an Achievement and as a Tool.” [In:] Charles Antaki and Sue Widdicombe (eds.) Identities in Talk. London: Sage; 1-14.

Aravossitas, Themistoklis (2016) The Hidden Schools: Mapping Greek Heritage Language in Canada [PhD Thesis, University of Toronto].

Archakis, Argiris (2014) “Immigrant Voices in Students' Essay Texts: Between Assimilation and Pride." Discourse and Society, 25(3); 297-314.

https://doi.org/10.1177/0957926513519539

Archakis, Argiris (2018) “The Representations of Racism in Immigrant Students' Essays in Greece: The 'Hybrid Balance' between Legitimizing and Resistance Identities.” Pragmatics, 28(1); 1-28.

Archakis, Argiris, Villy Tsakona (2012) The Narrative Construction of Identities in Critical Education. Basingstoke: Palgrave Macmillan. 
Archakis, Argiris, Villy Tsakona (2016) "Legitimizing and Resistance Identities in Immigrant Students' School Essays: Towards a Culturally Sustaining Pedagogy.” Brno Studies in English, 42(1); 5-22. https://doi.org/10.5817/BSE2016-1-1

Archakis, Argiris, Villy Tsakona (2018) “A Critical Literacy Proposal for Exploring Conflict and Immigrant Identities in the Classroom - or How Not to Sweep Conflict under the Multicultural Classroom Carpet." Journal of Language Aggression and Conflict, 6(1); 125. https://doi.org/10.1075/jlac.00001.arc

Bamberg, Michael (1997) “Positioning between Structure and Performance.” Journal of Narrative and Life History, 7 (1-4); 335-342. https://doi.org/10.1075/jnlh.7.42pos

Basch, Linda, Nina Glick Schiller, Cristina Szanton Blanc (1994) Nations Unbound: Transnational Projects, Postcolonial Predicaments, and Deterritorialized Nation-states. London: Gordon and Breach.

Bhabha, Homi (1994) The Location of Culture. London: Routledge.

Blommaert, Jan (2010) The Sociolinguistics of Globalization. Cambridge: Cambridge University Press.

Blommaert, Jan, Piia Varis (2011) "Enough is Enough: The Heuristics of Authenticity in Superdiversity." Tilburg Papers in Culture Studies, 2; 1-13.

Canagarajah, Suresh (2017) "Introduction. The Nexus of Migration and Language: The Emergence of a Disciplinary Space.” [In:] Suresh Canagarajah (ed.) The Routledge Handbook of Migration and Language. London: Routledge; 1-28.

Chimbos, Peter (1999) “Greeks.” [In:] Paul Robert Magocsi (ed.) Encyclopedia of Canada's Peoples. Toronto: University of Toronto Press; 615-626.

Constantinides, Stefanos (2004) The Presence of Greeks in Canada. Rethimno: University of Crete. [in Greek]

Cuenca, Maria Josep, Carme Bach (2007) "Contrasting the Form and the Use of Reformulation Markers.” Discourse Studies, 9(2); 149-175. https://doi.org/10.1177/1461445607075347

Davies, Brownyn, Rom Harré (1990) "Positioning: The Discursive Production of Selves." Journal for the Theory of Social Behavior, 20(1); 43-46. https://doi.org/10.1111/j.14685914.1990.tb00174.x

De Fina, Anna (2016) “Linguistic Practices and Transnational Identities.” [In:] Sian Preece (ed.) The Routledge Handbook of Language and Identity. London: Routledge; 163-178. De Fina, Anna, Alexandra Georgakopoulou (2011) Analyzing Narrative. Cambridge: Cambridge University Press. 
De Fina, Anna, Deborah Schiffrin, Michael Bamberg (eds.) (2006) Discourse and Identity. Cambridge: Cambridge University Press.

De Korne, Haley, Michael Byram, Michael Fleming (2007) "Familiarizing the Stranger:

Immigrant Perceptions of Cross-Cultural Interactions and Bicultural Identity." Journal of Multilingual and Multicultural Development, 28(4); 290-307.

https://doi.org/10.2167/jmmd462.0

Demjén, Zsófia, Elena Semino (2016) “Introduction: Metaphor and Language.” [In:] Elena Semino and Zsófia Demjén (eds.) The Routledge Handbook of Metaphor and Language. London: Routledge; 1-10.

Deppermann, Arnulf (2013) "Editorial: Positioning in Narrative Interaction." Narrative Inquiry, 23(1); 1-15. https://doi.org/10.1075/ni.23.1.01dep

Duff, Patricia (2015) “Transnationalism, Multilingualism, and Identity.” Annual Review of Applied Linguistics, 35; 57-80. https://doi.org/10.1017/S026719051400018X

Faist, Thomas (2000) The Volume and Dynamics of International Migration and Transnational Social Spaces. Oxford: Oxford University Press.

Gavaki, Efrosini (2003) “Immigrant Women's Portraits: The Socio-Economic Profile of the Greek Canadian Women.” The Greek Review of Social Research, 110; 55-75. http://dx.doi.org/10.12681/grsr.9166

Georgakopoulou, Alexandra (1997) Narrative Performances. A Study of Modern Greek Storytelling. Amsterdam: John Benjamins.

Georgakopoulou, Alexandra (2007) Small Stories, Interaction and Identities. Amsterdam: John Benjamins.

Georgakopoulou, Alexandra (2015) "Small Stories Research: Methods-Analysis-Outreach."

[In:] Anna De Fina and Alexandra Georgakopoulou (eds.) The Handbook of Narrative Analysis. Malden, MA: Wiley-Blackwell; 255-272.

Harré, Rom, Luk van Langenhove (1991) "Varieties of Positioning." Journal for the Theory of Social Behavior, 21(4); 393-407. https://doi.org/10.1111/j.1468-5914.1991.tb00203.x Harré, Rom, Luk van Langenhove (eds.) (1999) Positioning Theory. Oxford: Blackwell. Kalogeropoulou, Maria (2015) "Columns of the House and Proud Workers: Greek Immigrant Women in Vancouver, 1954-1975." PhD Thesis, Simon Fraser University. Kapllani, Gazmend (2006) A Short Border Handbook. Athens: Livanis. [in Greek] Karachaliou, Rania, Argiris Archakis (2015) "Reformulation in Conversational Narratives:

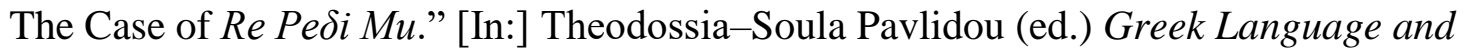


Oral Communication. Thessaloniki: Institute of Modern Greek Studies; 167-182. [in Greek]

Kövecses, Zoltán (2005) Metaphor in Culture. In Metaphor in Culture: Universality and Variation. Cambridge: Cambridge University Press.

Lakoff, George, Mark Johnson (1980) Metaphors We Live By. Chicago: University of Chicago Press.

Liebscher, Grit, Jennifer Dailey-O'Cain (2013) Language, Space and Identity in Migration. Basingstoke: Palgrave.

Malhi, Rebecca L., Susan D. Boon, Timothy B. Rogers (2009) “'Being Canadian' and 'Being Indian': Subject Positions and Discourses Used in South Asian-Canadian Women's Talk about Ethnic Identity." Culture and Psychology, 15(2); 255-283. https://doi.org/10.1177/1354067X09102893

Patrick, Donna (2010) “Canada.” [In:] Joshua A. Fishman and Ofelia García (eds.) Handbook of Language and Ethnic Identity. Oxford: Oxford University Press; 268-301.

Pennycook, Alastair, Emi Otsuji (2015) Metrolingualism: Language in the City. Abingdon: Routledge.

Rampton, Ben (2008) Language in Late Modernity: Interaction in an Urban School. Cambridge: Cambridge University Press.

Sarbin, Theodore R., John I. Kitsuse (1994) “A Prologue to 'Constructing the Social'.” [In:] Theodore R. Sarbin and John I. Kitsuse (eds.) Constructing the Social. London: Sage; 117.

Schegloff, Emanuel A., Gail Jefferson, Harvey Sacks (1977) “The Preference for Selfcorrection in the Organization of Repair in Conversation." Language, 53(2); 361-382.

Simmel, Georg ([1908] 1971). On Individuality and Social Norms. Selected Writings. Edited by Donald N. Levine. Chicago: The University of Chicago Press.

Simmel, Georg ([1908] 2009). Sociology. Inquiries into the Construction of Social Forms. Vol. I. Translated and edited by Anthony J. Blasi, Anton K. Jacobs and Mathew Kanjirathinkal. Leiden: Brill.

Smith, Michael Peter, Luis Eduardo Guarnizo (eds.) (1998) Transnationalism from Below. New Brunswick: Transaction Publishers.

Tamis, Anastasios M., Efrosini Gavaki (2002) From Migrants to Citizens: Greek Migration in Australia and Canada. Melbourne, Australia: National Centre for Hellenic Studies and Research. 
van Bochove, Marianne, Jack Burgers, Amber Geurts, Willem de Koster, Jeroen van der Waal (2015) “Questioning Ethnic Identity: Interviewer Effects in Research about Immigrants' Self-definition and Feelings of Belonging.” Journal of Cross-Cultural Psychology, 46(5); 652-666. https://doi.org/10.1177/0022022115576961

van Langenhove, Luk, Rom Harré (1999) “Introducing Positioning Theory.” [In:] Rom Harré and Luk van Langenhove (eds.) Positioning Theory. Oxford: Blackwell; 14-31.

van Dijk, Teun A. (1992) "Discourse and the Denial of Racism." Discourse and Society, 3(1); 87-118. https://doi.org/10.1177/0957926592003001005

Verkuyten, Maykel and Angela deWolf (2002) "Being, Feeling and Doing: Discourses and Ethnic Self-definitions among Minority Group Members.” Culture and Psychology, 8(4); 371-399. https://doi.org/10.1177/1354067X0284001

Vertovec, Steven (2004) "Migrant Transnationalism and Modes of Transformation." International Migration Review, 38(3); 970-1001.

Vertovec, Steven (2009) Transnationalism. London: Routledge.

Wodak, Ruth, Rudolf de Cillia, Martin Reisigl, Karin Liebhart (1999) The Discursive Construction of National Identity. Edinburgh: Edinburgh University Press. 